Sonia Maria Melchiorre

Università degli Studi della Tuscia

\title{
HUMBLY DISSENTING. REVISITING ITALIAN TRANSLATION OF EIGHTEENTH-CENTURY VINDICATIONS FOR THE RIGHTS OF WOMEN IN THE TWENTY-FIRST CENTURY
}

\begin{abstract}
The translator, in her/his activity, has always resembled Janus Bifrons, the god of transitions, passages and endings looking, simultaneously, to the past and the future . This is particularly the case of the translation of texts produced by women in the past centuries. In translating women's writing other competences and skills are, in fact, necessary in order to better (re)present the revolutionary ideas concealed behind an apparently conventional use of language in their own time. In this contribution, the authoress illustrates the difficulties in translating, from English to Italian, the vindications for the right to education produced by some British women writers of the eighteenth century.
\end{abstract}

Keywords: eighteenth-twenty-first century, literature, translation, women

Umilmente dissento. Rileggendo le traduzioni italiane del romanzo settecentesco sulle rivendicazioni dei diritti delle donne nel XXI secolo

Riassunto

Il traduttore / la traduttrice nella sua attività sempre assomiglia a Giano Bifronte, divinità di transizione, del passaggio e della fine che può guardare simultaneamente il passato e il futuro.

È questo il caso della traduzione dei testi prodotti dalle donne nei secoli passati. Nel tradurre delle scritture femminili altre competenze e capacità sono, infatti, necessarie al fine di rappresentare meglio le idee rivoluzionarie nascoste dietro l'uso apparentemente convenzionale della lingua. In questo contributo l'autrice illustra alcune difficoltà della traduzione inglese-italiana delle rivendicazioni dei diritti delle donne all'istruzione presentate da alcune scrittrici britanniche del Settecento.

Parole chiave: donne, letteratura, Settecento, traduzione 
The translator's discoveries then come as it were to revitalize or regenerate the text, renewing its secret energy. From this point of view, translation can liberate forces which had remained hidden to native speakers and critics.

(Serpieri, Elam, 2002: 4)

Twenty-first-century translators are well aware of all the translation approaches proposed in the past and are also very conscious about their role as cultural mediators, and in some cases of interpreters, of texts. Moreover, in the post-structuralist era they are also overtly asked not to disappear from the text, or stay behind the curtains.

The so called cultural turn in translation studies of the 1960s, and its most respected representatives Bassnett and Lefevere (1998) started in the 1990s an irreversible process which has more recently led to consider translation a very personal expression on the part of someone - the translator - who is not only drenched in the culture of the time but who becomes an activist and uses the text possibly to produce change at both social and political level. ${ }^{1}$

The translators' most valuable tool is still a deep knowledge of the subject they are dealing with. In translating the text, though, they must also keep into account several additional things: first, they have to consider the gender of the author of the source text - the fact that the writer is man or a woman is, for instance, particularly relevant in the case of the texts cited in this contribution; second, the translator, should not hesitate to propose alternative options - i.e in the footnotes - when dealing with particularly relevant keywords and concepts whose connotations tend to disappear in the text. Last but not least, the translator should adopt the perspective that Mona Baker has recently defined "ethical" (Baker, 1992/2018).

Why is the translation of texts, and religious texts in particular, produced by women in the eighteenth century, so relevant for our contemporary culture?

The recovery, reproduction and study of texts produced by women in the past have always been presented as part of a deep digging into culture. The translation of such texts explicitly shows the contribution of a category of scholars in adding new meanings to unknown, known and well-known texts.

Translation practice, in the twenty-first century, should be like a $3 \mathrm{D}$ projection where the translator functions as the special glasses for the audience.

1 See Mary Snell-Hornby (2006), Michaela Wolf (2007), Michaela Wolf and Alexandra Fukari (2007), Michaela Wolf (2012), and Brian Baer and Klaus Kaindl (2017). 


\section{Cultural framework. End of the XVII century - End of the XVIII century}

Let's start with the first document's date. 1688 is the year of the Glorious Revolution, so denominated because it represented a "peaceful" revolt against any forms of authority. At the time of the Civil War, many women exposed themselves expressing their thoughts and feelings against patriarchal authority implied in the very idea of Monarchy. They also fought against the accepted physical aggression and violence against the wives accepted by the law, and supported the idea of divorce as a right for those women betrayed by their husbands. The rebellion against the King, the Father figure par excellence, represented the first symptom of a social and political change which would obviously impact the family hierarchical structure and the future development of the relationships between its members.

Mary Astell's most relevant publications appeared between the last decade of the XVII century and the first decade of the following century. She could have relied on the Restoration Comedies' transgressive narratives. She willingly decided to ignore their cultural impact and harshly criticized the authors of such texts calling them "dangerous public enemies" because their open intent to subvert the hierarchical structure of the family.

How could this woman be considered a "feminist" in her own time? Her works are to be considered extremely subversive for several reasons: first, the stress on the importance of creating a protected space for the "ladies" of the best families; second, the study of both science and humanities for all women; third, but most important, her idea of hierarchy put God on the top, this meant that also men were subjects to power and not of power, exactly like women.

The Age of Enlightenment is introduced in the following excerpts by Daniel Defoe's Essays Upon Projects dating back to 1697 and is followed by Richard Steel - the creator of The Spectator - and his Lady's Library.

Finally, the most illustrious example of a well-educated woman, among the many presented in this brief contribution, is represented by Hester Mulso Chapone. She befriended many of the great writers of her time - Samuel Richardson in particular - but most importantly she anticipated some of the revolutionary ideas proposed in Mary Wollstonecraft's $A$ Vindication for the Rights of Woman (1794) - Chapone was mentioned by Wollstonecraf in her work, which thing she didn't really appreciate!

Translating these works into contemporary Italian implies a whole set of notions - if not deep knowledge - of the context in which they were produced, in order not to repeat the mistake made by the feminists from the 1970s to the 1990s, who willingly refused to read and publish them. 
Since the 1990s much has been done to recover and republish many works by apparently non/anti-revolutionary and conservative women. We have learnt to read between the lines, to interpret their rhetorical strategies and translate so to render visible what was already there: the multiple connotation of noncasually used words and terminology. ${ }^{2}$

Ex. 1 Anonymous, Female Excellency, or The Ladies Glory (1688)

\begin{tabular}{|l|l|}
\hline \multicolumn{1}{|c|}{ ENGLISH } & \multicolumn{1}{|c|}{ ITALIAN } \\
\hline $\begin{array}{l}\text { Men have the advantage of education }[. . .] \\
\text { If women had the same helps, I dare not say but } \\
\text { they could make as good returns, of which there } \\
\text { have been many famous instances in former }\end{array}$ & $\begin{array}{l}\text { Gli uomini godono del vantaggio } \\
\text { delledonione [...] }\end{array}$ \\
Ages. (Anonymous, 1688: 38) & $\begin{array}{l}\text { escluderei che esse possano raggiungere i loro } \\
\text { medesimi risultati, come dimostrano illustri } \\
\text { esempi del Passato. }\end{array}$ \\
\hline
\end{tabular}

Source: Own study.

Ex. 2. D. Defoe, Essays upon Project (1697)

\begin{tabular}{|c|c|}
\hline ENGLISH & ITALIAN \\
\hline $\begin{array}{l}\text { Most barbarous Custom [...] that deny the } \\
\text { advantages of Learning to Women. We reproach } \\
\text { the Sex every day with Folly and Impertinence, } \\
\text { while I am confident, had they advantages of } \\
\text { Education equal to us, they wou'd be guilty } \\
\text { of less than ourselves. One wou'd wonder } \\
\text { indeed how it shou'd happen that Women are } \\
\text { conversible at all, since they are only beholding } \\
\text { to Natural Parts for all their Knowledge [...] } \\
\text { And I wou'd but ask who slight the Sex for their } \\
\text { Understanding, what is a Man (a Gentleman, } \\
\text { I mean) good for, that is taught no more? } \\
\text { (Turner, 1992: 71) }\end{array}$ & $\begin{array}{l}\text { La più Barbara delle Consuetudini [...] } \\
\text { nega i vantaggi del Sapere alle Donne. } \\
\text { Rimproveriamo l'altro Sesso ogni giorno per } \\
\text { la sua Follia e Impertinenza, mentre ritengo, } \\
\text { che se godessero dei nostri stessi vantaggi } \\
\text { nell'Educazione, esse sarebbero anche meno } \\
\text { biasimevoli di noi uomini. } \\
\text { Viene da domandarsi, invero, come possa } \\
\text { essere possibile che le Donne siano in grado } \\
\text { anche solo di Conversare, dal momento } \\
\text { che la loro conoscenza è limitata a ciò che } \\
\text { rimirano allo specchio [...] } \\
\text { E vorrei domandare a coloro che offendono } \\
\text { l'altro Sesso per il suo scarso Discernimento, } \\
\text { di cosa sarebbe capace un Uomo (un } \\
\text { Gentiluomo, intendo), se si smettesse di } \\
\text { insegnargli? }\end{array}$ \\
\hline
\end{tabular}

Source: Own study.

${ }^{2}$ For a more in depth cultural analysis see Melchiorre, 2013. 
At a time when women could not even easily access a basic education, they had to publish anonymously. The verb "to dare" (osare) in the expression is one of the most recurrent in the literary production of women writers of the time. Unfortunately, it partly loses its political charge when translated into Italian. "Non escluderei", the proposed translation, though, helps the translator introduce the ironic tone underlying most of the texts presented in this contribution. Moreover, the Italian text "possano raggiungere i loro - meaning "men" - helps stressing the idea of the battle of the sexes, whilst "they could make as good returns" in the original text only refers to "returns".

Written when Mary Astell had just published the first part of A Serious Proposal to the Ladies (1697) "barbarous, folly, impertinence," are all words negatively connoted associated with the man and belonging to the same semantic field. The reproachful tone is part of this famous advocacy for the right to education, an issue which would become "fashionable" among intellectuals of the Long Eighteenth Century. Very relevant is also the reference to one of the most important activities performed by the members of polite society, that is "conversation" and is here rendered with the verb "conversare".

Ex. 3. Richard Steele, The Ladies Library (1714)

\begin{tabular}{|c|c|}
\hline ENGLISH & ITALIAN \\
\hline $\begin{array}{l}\text { It would be an endless talk should we undertake } \\
\text { to give the instances of the great improvements } \\
\text { which women have made of education, there } \\
\text { being hardly any science in which some of them } \\
\text { have not excelled. It is very plain, therefore, that } \\
\text { nature has given them as good talents as men } \\
\text { have, and if they are still called the weaker sex, } \\
\text { it is because the other, which assumes the name } \\
\text { of the wiser, hinders them form improving their } \\
\text { minds in useful knowledge, by accustoming } \\
\text { them to the study and practise of vanity and } \\
\text { trifles. (Steele, 1714: 535) }\end{array}$ & $\begin{array}{l}\text { Sarebbe troppo lungo fornire esempi } \\
\text { dei grandi progressi che le donne hanno } \\
\text { fatto grazie all'istruzione, non essendovi } \\
\text { praticamente alcuna scienza in cui alcune di } \\
\text { loro non siano riuscite in maniera eccellente. } \\
\text { Appare ovvio dunque, che la natura le abbia } \\
\text { dotate di tanto talento quanto gli uomini, } \\
\text { e se sono ancora definite il sesso debole, } \\
\text { è perché l'altro, che si arroga il titolo di } \\
\text { forte, impedisce loro di migliorare le loro } \\
\text { menti attraverso una conoscenza più utile, } \\
\text { rendendole avvezze invece allo studio e alla } \\
\text { pratica della vanità e delle sciocchezze. }\end{array}$ \\
\hline
\end{tabular}

Source: Own study.

Richard Steele was better known in his own time for being the originator of one of the first newspapers, The Tatler, with Joseph Addison. The piece cited here follows the educational example of the Tatler, distributed in cafès and pubs in London to educate common people and offering news on any aspect of culture. Here "Science and Reason" and "Nature and Feeling", two fields of study usually 
kept separated are brought together to support the idea that women's brains are able to process scientific knowledge. The most relevant passage, well rendered in Italian. "Assumes", with the meaning of "assumere, dedurre" in Italian, is strengthened in the translation through the use of the verb "arroga" denotes a position of power on the part of the man not derived from God and not even from Nature, but self-proclaimed.

Ex. 4. M. Astell, Some Reflections upon Marriage (1700)

\begin{tabular}{|c|c|}
\hline ENGLISH & ITALIAN \\
\hline $\begin{array}{l}\text { For there is a mutual Stipulation, and Love, } \\
\text { Honour and Worship, by which certain Civility } \\
\text { and Respect at least are meant, are as much the } \\
\text { Woman's due, as Love, Honour, and Obedience } \\
\text { are theMan's, and being the Woman said } \\
\text { to be the weaker Vessel, the Man shou'd be more } \\
\text { careful not to grieve or offend her. (Astell, 1700: } \\
62-63 \text { ) }\end{array}$ & $\begin{array}{l}\text { Esiste una mutua Stipulazione, e Amore, } \\
\text { Onore e Venerazione, che implica una certa } \\
\text { Civiltà e Rispetto da parte della Donna, così } \\
\text { come Amore, Onore, e Obbedienza sono } \\
\text { dovuti dall'Uomo; ed essendo la donna } \\
\text { considerata il Sesso debole, l'Uomo dovrebbe } \\
\text { essere più accorto a non darle dispiaceri } \\
\text { e a non arrecarle offesa. }\end{array}$ \\
\hline
\end{tabular}

Source: Own study.

Ex. 5. Mary Astell, Some Reflections upon Marriage (1700)

\begin{tabular}{|c|c|}
\hline ENGLISH & ITALIAN \\
\hline $\begin{array}{l}\text { Have not all the great Actions that have been } \\
\text { perform'd in the world been done by Men? } \\
\text { Have not they founded Empires and overturn'd } \\
\text { them? Do not they make Laws and continually } \\
\text { repeal and amend them? Their vast Minds lay } \\
\text { Kingdoms waste, no Bounds or Measures can be } \\
\text { prescrib'd to their Desires [...] What is it they } \\
\text { cannot do? They make worlds and ruin them, } \\
\text { form Systems and universal Nature and dispute } \\
\text { eternally about them. (Astell, 1700: } 81 \text { ) }\end{array}$ & $\begin{array}{l}\text { Le gesta Eroiche dell'umanità non sono forse } \\
\text { state compiute da Uomini? } \\
\text { Non hanno essi creato Imperi che poi hanno } \\
\text { distrutto? Non promulgano essi Leggi che di } \\
\text { continuo contestano e modificano? Le loro } \\
\text { Menti sconfinatamente grandi conducono } \\
\text { Regni alla rovina, né Confini, e nessun } \\
\text { Limite può essere imposto ai loro Desideri } \\
\text { [...] Cos'è che essi non possono? } \\
\text { Creano mondi che poi distruggono, } \\
\text { inventano Sistemi e la Natura tutta per } \\
\text { speculare in eterno su di essi. }\end{array}$ \\
\hline
\end{tabular}

Source: Own study.

The rhetoric of gender difference is made manifest and even stressed in this excerpt creating two different semantic clusters: love, honour, worship are associated with the woman, and love, honour and obedience with man. The 
relationship is not, though, between the two sexes, but with each sex and God. That the religious register is the most relevant to consider, is also underlined by the reference to the woman as "weaker vessel" - the expression used in the Bible to define women. In Italian this connotation is unfortunately lost and rendered with the locution "sesso debole" (weaker sex).

This passage is particularly interesting for the unusual use of irony on the part of a religious woman writer. Irony, we have learnt from Bakhtin and Kristeva, is a very powerful weapon to subvert power relations. Women are willingly kept out of the picture and man's power is ridiculed though the use of expressions such as "great actions/gesta eroiche", only aimed to destroy, always contrasted with God's positive power.

Ex. 6. M. Astell, A Christian Religion as Profess'd by A Daughter of the Church of England (1705)

\begin{tabular}{|l|l|}
\hline \multicolumn{1}{|c|}{ ENGLISH } & \multicolumn{1}{|c|}{ ITALIAN } \\
\hline If God had not intended that women should use & Se Dio non avesse voluto che le donne \\
their reason, He would not have given them any, & usassero la loro capacità di discernimento, \\
for He does nothing in vain. If they are to use & Egli non gliene avrebbe fatto dono, poiché \\
their reason, certainly it ought to be employed & Egli nulla compie invano. Se esse dovessero \\
about the noblest objects, and in business of the & usare tale capacità, di certo questa dovrebbe \\
greatest consequence, therefore, in religion. [...] & essere impiegata per i più nobili propositi, \\
A Christian woman therefore must not be & e nelle questioni della più grande importanza, \\
a child in understanding; she must serve God & dunque, nella religione. [...] \\
with understanding as well as with affection; & Una donna cristiana non deve perciò avere un \\
must love Him with all her mind and soul, & discernimento pari a quello di un bambino. \\
as well as with all her heart and strength; in & Ella deve servire Dio con raziocinio e affetto, \\
aword, must perform a reasonable service if she & e deve amarlo con tutta la mente e l'anima, \\
means to he acceptable to her maker. (Astell, & e con tutto il cuore. In una parola, ella deve \\
1705: 260) & rendergli merito per tale dono, se intende \\
& essere degna del suo creatore. \\
\hline
\end{tabular}

Source: Own study.

It was common practice, among these "pious" women writers, to refer to the supreme authority of God in order to equal them to men. Hence expressions such as "If God had not intended/Se Dio non avesse voluto", or "she must serve God, must love Him... her maker", which in this case can be perfectly rendered in Italian through the redundant use of personal pronouns and possessives, instrumental - in both texts - to highlight the "subject-ed" position of both men and women in such a "godly" hierarchy. 
Ex. 7. Catherine Talbot, Reflections on the Seven Days of the Week (1770)

\begin{tabular}{|l|l|}
\hline \multicolumn{1}{|c|}{ ENGLISH } & \multicolumn{1}{|c|}{ ITALIAN } \\
\hline $\begin{array}{l}\text { It is by no Means enough to be rigidly disposed, } \\
\text { to be serious, and religious in our Closets: We }\end{array}$ & $\begin{array}{l}\text { Non è certo sufficiente votarci e essere serie } \\
\text { must be useful too, and take Care, that as we }\end{array}$ \\
all reap numberless Benefits from Society, may & anche renderci utili, e prenderci cura del \\
pe better for everyone of us. It is a false, a faulty, & trae innumerevoli Benefici dalla Società. \\
and an Indolent Humility, that make People & Ciò tornerebbe a vantaggio di tutti. È falsa, \\
sit still and do nothing, because they will not & erronea e indolente l'umiltà che ci fa restare \\
believe, that they are capable of doing much: & apatiche nella nostra immobilità, poiché si \\
For every Body can do something. Every Body & ritiene di non poter fare molto. Ma ciascuno \\
can set a good Example, be it to many, or to few. & di noi può fare qualcosa; ciascuno può offrire \\
Every Body can in some Degree encourage & un Contributo, piccolo o grande che sia. \\
Virtue and Religion, and discountenance Vice & Ciascuno può, in qualche modo, incoraggiare \\
and Folly. Every Body has some one or other & la Virtù e la Religione ed evitare il Vizio e la \\
whom they can advice or instruct, or in some & Follia. Ciascuno può consigliare o istruire in \\
Way help to guide through life. (Talbot, 1770: & qualche Maniera, guidare qualcun altro nel \\
56) & percorso della Vita. \\
\hline
\end{tabular}

Source: Own study.

Of all the women writers considered in this contribution, Talbot is surely the most "humbly dissenting". The rhetorical power of her work is soundly founded on the main isotopy of passivity and immobility negatively connoted so to expose the non-Christian principle of uselessness of women supported by patriarchal culture. "False, faulty, indolent humility, sit still and do nothing" are opposed to an active Christian living "every Body can do something, set a good Example, encourage Virtue, help to guide". It was surely not lost on Talbot that the only proper available job for an educated woman was teaching. Of particular relevance in the translation are the rendering of the word "closets/stanze", in the original implying the power imbalance imposed by culture and introjected by women.

The most outspoken of the so called proto-feminists considered in this brief work, Hester Mulso Chapone became a ground-breaker - trend-setter to use today's juvenile jargon - as she anticipated the work of the more famous Mary Wollstonecraft Vindication of the Rights of Woman (1792). This latter referred to Mulso Chapone as an example but Chapone kindly rebuked her and never wanted to be associated with Wollstonecraft in public. 
Ex. 8. Hester Mulso Chapone, Letters on the Improvement of the Mind (1773)

\begin{tabular}{|l|l|}
\hline \multicolumn{1}{|c|}{ ENGLISH } & \multicolumn{1}{|c|}{ ITALIAN } \\
\hline [...] But, as I do not wish you to impose on the & Ma dal momento che spero non vorrai \\
world your appearance, I should be contend & imporre la tua apparenza al mondo, sarei \\
to see you worse dressed, rather than see your & contenta di vederti peggio vestita, piuttosto \\
whole time employed in preparations for it - or & che impegnata tutto il tempo nei preparativi \\
any of the hours given to it, which are needful & - o in qualunque ora ad essa dedicata, \\
to make your body strong and active by exercise, & necessaria per rendere il tuo corpo forte \\
or your mind rational by reading. Absolute & e attivo attraverso l'esercizio fisico, o la tua \\
idleness is inexcusable in a woman, because & mente razionale per via della lettura. L'ozio \\
the needle is always at hand for those intervals, & è cosa deprecabile in una donna, perché \\
in which she cannot be otherwise employed. & l'ago è sempre a portata di mano per quegli \\
(Mulso Chapone, 1773: 319) & intervalli, in cui essa non possa essere \\
& impegnata in altro modo. \\
\hline
\end{tabular}

Source: Own study.

The most relevant passage of the excerpt revolves around Chapone's protestations against the machist culture of her own time, when women were considered unable even to grasp the basic meaning of abstract thought. The keyword "exercise/esercizio" is given here particular relevance and is connected with a more rational, enlightened and non-religious stance.

\section{Conclusions}

To conclude with, twenty-first-century translations of eighteenth-century works produced by women writers should be considered part of a feminist approach to literary texts and also the starting point for the ongoing process of social and political activism in the field of translations studies embodying a "new" trend in this theoretical field of study.

\section{Bibliography}

Anonymous (1688): Female Excellency, or The Ladies Glory: illustrated in the worthy lives and memorable actions of nine famous women, who have been renowned either for virtue or valour in several ages of the world ... the whole adorned with poems and the picture of each lady. Printed by Nathaniel Crouch, in London and republished in 2010 by Gale Ecco, Print Editions, USA. In: Schoefield, M., Macheski, C. (eds) (1986): Fetter'd or Free? British Women Novelists 1670-1815, p. 38. Athens: Ohio University Press. 
Astell, M. (1705): A Christian Religion as Profess'd by A Daughter of the Church of England. In: Rowell, G., Stevenson K., Williams R. (eds) (2001): Love's Redeeming Work: The Anglican Quest for Holiness, pp. 253-261. Oxford: Oxford University Press.

Astell, M. (1700): Some Reflections upon Marriage. 4th edn. Printed for William Parker, at the King's Head in St. Paul's Church-Yard, 1730.

Baer, B., Kaindl, K. (eds) (2017): Queering Translation, Translating the Queer. Theory, Practice, Activism. New York-London: Routledge.

Baker, M. (1992/2018): In Other Words. A Coursebook on Translation. London-New York: Routledge.

Bassnett, S., Lefevere, A. (eds) (1998): Constructing Cultures. Essays on Literary Translation. Clevedon-Philadelphia-Toronto-Sydney-Johannesburg: Multilingual Matters.

Mulso Chapone, H. (1773): Letters on the Improvement of the Mind, addressed to a young Lady, 2 vols. Londra: J. Walter. Reprinted with a Father's Legacy to his Daughters by Dr. Gregory. A Mother's Advice to her Absent Daughters, with an additional letter on the management and education of infant children, by Lady Pennington (1830). New York: W. Marks. Collected for the first time in The Works of Mrs. Chapone. Now First Collected ... to which is prefixed, An Account of Her Life and Character, drawn up By Her Own Family (1809), 2 vols. Londra: W. Wells and T.B. Wait and Co. In: Zuk, R. (ed.), Catherine Talbot and Hester Mulso Chapone. In: Kelly, G. (ed.) (1999): Bluestocking Feminism: Writings of the Bluestocking Circle, 1738-1785, vol. 3. London: Pickering and Chatto.

Melchiorre, S.M., (2013): Quando la lingua del Signore è di un genere diverso: "femminismo" e religione nella letteratura inglese tra XVII e XVIII secolo. Con traduzioni dall' inglese. Viterbo: Settecittà.

Serpieri, A., Elam, K. (2002): Preface: Towards a Poetics of Translation. Textus. English Studies in Italy, Serpieri, A., Elam, K. (eds), XV, 1, pp. 3-10.

Snell-Hornby, M. (2006): The Turns of Translation Studies. New Paradigms or Shifting Viewpoints? Amsterdam: John Benjamins.

Steele, R. (1714): Ladies Library. Written by a Lady, 3 vols. London: Jacob Tonson, http://www.luninarium.org/eightlit/steele/steelebib.htm (accessed 17 Jan, 2020).

Talbot, C. (1770): Reflections on the Seven Days of the Week. In: Zuk, R. (ed.), Catherine Talbot and Hester Mulso Chapone. In: Kelly, G. (ed.) (1999): Bluestocking Feminism: Writings of the Bluestocking Circle, 1738-1785, vol. 3. London: Pickering and Chatto.

Turner, C. (1992): Living by the Pen: Women Writers in the Eighteenth Century. LondonNew York: Routledge.

Wolf, M. (2007): Introduction. The Emergence of a Sociology of Translation. In: Wolf M., Fukari A. (eds), Constructing a Sociology of Translation, pp. 1-36. Amsterdam: John Benjamins.

Wolf, M. (2012): The Sociology of Translation and Its 'Activist Turn'. Translation and Interpreting Studies, 7(2), pp. 129-143.

Wolf, M., Fukari, A. (eds) (2007): Constructing a Sociology of Translation. Amsterdam: John Benjamins. 